\title{
PATHOLOGICAL FRACTURES DUE TO BONE METASTASES FROM LUNG CANCER: RISK FACTORS AND SURVIVAL
}

\section{FRATURA PATOLÓGICA DEVIDO À METÁSTASE ÓSSEA DO CÂNCER DE PULMÃO: FATORES DE RISCO E SOBREVIDA}

\author{
Marcelo Bragança dos Reis Oliveira ${ }^{1,2}$, Bruno de Carvalho Marques ${ }^{1}$, Rosa Aurílio Matos ${ }^{2}$, César Rubens da Costa Fontenelle ${ }^{1}$, \\ Fernanda Carvalho de Queiroz Mello ${ }^{1}$, Marcos Eduardo Machado Paschoal ${ }^{2}$
}

1. Universidade Federal do Rio de Janeiro, Rio de Janeiro, RJ, Brazil.

2. Escola de Saúde do Exército, Rio de Janeiro, RJ, Brazil.

\section{ABSTRACT}

Introduction: Pathological fractures are frequent skeletal-related events among lung cancer patients, which result in high morbidity and decreased overall survival and make operative treatment decisions challenging. Objectives: To identify risk factors associated with the occurrence of pathological fractures in patients with lung cancer and to determine survival. Methods: We conducted a retrospective cohort study with 407 lung carcinoma patients diagnosed between 2006 and 2015. The prevalence of bone metastases and pathological fractures was calculated. Statistical analysis was conducted using a chi-squared test, and the odds ratio and 95\% confidence interval were calculated. Overall survival was determined using the Kaplan-Meier method and differences were compared using the log-rank test. Results: The prevalence of bone metastases and pathological fractures was $28.2 \%(n=115)$ and $19.1 \%(n=22)$, respectively. Pathological fractures were more frequent among patients with bone metastases at the time of diagnosis of lung cancer $(24.7 \%$ [ $n=20]$ vs. $5.9 \%$ [n $=2] ; p<0.05)$. The median overall survival following the diagnosis of lung cancer, bone metastases, and pathological fracture was 6 , 4, and 2 months, respectively. Conclusions: Pathological fracture was associated with synchronous bone metastases and overall survival times were considerably reduced. Level of Evidence IV, Case Series.

Keywords: Lung neoplasms, Bone, Fractures.

\section{RESUMO}

Introdução: Fratura patológica é um evento esquelético frequente em pacientes com câncer de pulmão, resultando em alta morbidade e sobrevida global reduzida que torna a decisão de tratamento cirúrgico desafiadora. Objetivos: Identificar fatores de risco associados à ocorrência de fraturas patológicas em pacientes com câncer de pulmão e determinar a sobrevida. Métodos: Conduzimos um estudo retrospectivo de coorte com 407 pacientes diagnosticados com carcinoma pulmonar entre 2006 e 2015. A prevalência de metástase óssea e fratura patológica foi calculada. Análise estatística foi conduzida usando o teste X2, e razão de chances e o intervalo de confiança de $95 \%$ foi calculado. A sobrevida global foi determinada usando o método de Kaplan-Meier e as diferenças foram comparadas usando o teste do log-rank. Resultados: A prevalência de metástases ósseas e fraturas patológicas foi de 28,2\% ( $n=115)$ e 19,1\% $(n=22)$, respectivamente. Fraturas patológicas foram mais frequentes em pacientes com metástases ósseas ao diagnóstico do câncer de pulmão $(24,7 \%$ [ $n=20]$ vs. 5,9\% [n=2]; $p<0.05)$. A sobrevida global média após o diagnóstico do câncer de pulmão, da metástase óssea e da fratura patológica foram 6, 4 e 2 meses, respectivamente. Conclusão: Fratura patológica foi associada à metástase óssea sincrônica e a sobrevida global consideravelmente reduzida. Nível de Evidência IV. Série de Casos.

Descritores: Neoplasias pulmonares. Osso. Fraturas.

Citation: Oliveira MBR, Marques BC, Matos RA, F ontenelle CRC, Mello FCQ, Paschoal MEM. Pathological fractures due to bone metastases from lung cancer: risk factors and survival. Acta Ortop Bras. [online]. 2018;26(6):388-93. Available from URL: http://www.scielo.br/aob.

\section{INTRODUCTION}

The bone represents one of the most frequent sites of metastases from lung cancer, occurring in approximately $15-40 \%$ of patients. ${ }^{1}$ Skeletal-related events (SREs) are prevalent among these patients, resulting in high morbidity and a reduced quality of life. ${ }^{2,3}$ Despite the negative impact of bone metastases (BMs) on lung cancer prognosis, the unpredictability of survival makes an indication of palliative surgery challenging. Therefore, the elucidation of factors that can determine which patients will survive for a longer or shorter time is fundamental in guiding optimal treatment decisions.

In previous studies conducted by Oliveira et al., adenocarcinoma was associated with the higher risk of developing BMs. ${ }^{3,4}$ Therefore, we postulated that lung cancer histological subtype could also be correlated with the occurrence of PFs. In this study, we aimed to identify risk factors associated with the occurrence of PFs in patients with BMs from lung cancer and to assess the impact of this SRE

All authors declare no potential conflict of interest related to this article.

Study performed at the Hospital Universitário Clementino Fraga Filho, Universidade Federal do Rio de Janeiro.

Correspondence: Marcelo Bragança dos Reis Oliveira. Serviço de Traumato-Ortopedia do Hospital Universitário Clementino Fraga Filho da Universidade Federal do Rio de Janeiro.

Rua Rodolpho Paulo Rocco, 255, Cidade Universitária, Ilha do Fundão, Rio de Janeiro, RJ, Brazil. 21941-913. marceloreis@hucff.ufrj.br 
on survival. This analysis can support the decision to surgically treat these patients, or not, and identify in which patient palliative surgery would be better indicated.

\section{MATERIALS AND METHODS}

The medical records of 413 patients who had been diagnosed with malignant primary lung tumors at our institution between 2006 and 2015 were retrospectively evaluated. Inclusion criteria included a pathological confirmation of lung carcinoma and complete tumor staging data. Lung carcinomas were stratified based on the World Health Organization's classification system: adenocarcinoma (ADC), squamous cell carcinoma (SCC), large-cell carcinoma (LCC), NSCLC not otherwise specified (NOS), and SCLC. ${ }^{5}$

Events of interest included BMs and PF occurrence, and death. BMs were diagnosed by histopathological examination or using Technetium-99m bone scintigraphy with two additional imaging modalities (plain films and computed tomography or magnetic resonance imaging). BMs and PFs were classified, according to the time of diagnosis of the primary tumor, as either synchronous or metachronous. Collected variables included age, sex, smoking status, histological subtype, metastatic sites, a PF, the time of diagnosis of BMs and PFs in relation to the time of diagnosis of the primary tumor, and survival. Patients diagnosed with a second malignant primary tumor who had an unknown date of death were excluded from survival analysis. The minimum follow-up period following a diagnosis of BMs was 24 months, excluding patients with a survival of $<24$ months. The proportions of the variables among patients who developed or did not develop a PF were compared using a chi-squared test. The relationship between the variables and the occurrence of a PF was also evaluated using odds ratios (ORs) and 95\% confidence intervals (Cls). Overall survival (OS) and associations with the variables were analyzed using the Kaplan-Meier method. Differences between patients who developed or did not develop a PF, in addition to a synchronous or metachronous PF, were evaluated using the log-rank test. All statistical analyses were performed using Statistical Package for the Social Sciences for Windows, software version 10.0 (SPSS Inc., Chicago, IL, USA). A $p<0.05$ was considered statistically significant.
The study protocol was approved by the appropriate Institutional Review Board committee (protocol number 113/11). All study participants provided written informed consent and research was conducted in accordance with the Declaration of Helsinki.

\section{RESULTS}

Among 413 lung cancer patients, 407 (98.5\%) who met the inclusion criteria for histological subtype were analyzed. The patients' clinicopathological characteristics are summarized in Table 1, and a cohort diagram is presented in Figure 1.

ADC was the most prevalent histological subtype $(46.7 \% ; n=190)$, followed by SCC $(25.1 \% ; n=102)$.

The prevalence of BMs was $28.3 \%(n=115)$. Synchronous BMs occurred significantly more frequently than metachronous BMs (19.9\% $[n=81]$ vs. $8.4 \%[n=34] ; p<0.01)$. In total, 79 patients experienced 122 SREs, with an overall prevalence of $68.7 \%$ among patients with BMs. Radiotherapy was the most frequent SRE $(60.7 \% ; n=74)$, followed by PF $(19.1 \% ; n=22)$, spinal cord compression $(9.0 \% ; n=11)$, surgical treatment for BMs $(6.6 \% ; n=8)$, and hypercalcemia $(5.7 \% ; n=7)$ (Figure 1$)$.

PF fracture was more common among ADC patients $(23.9 \% ; n=16)$. The Figure 2 shows the prevalence of PFs according to lung cancer histology. Among 115 patients with BMs, 305 BMs and 22 PFs occurred. The most frequent site of BMs and PFs included the spine $(32.1 \% ; n=98)$ and humerus $(36.4 \%, n=8)$, (Figure 3 ).

To evaluate the relationship between the patients' clinicopathological characteristics and the occurrence of PFs, we compared the prevalence of histological subtype, smoking, synchronous or metachronous BMs, and the location of BMs in patient groups with or without PFs (Table 3). Among patients who developed a PF, the prevalence of ADC, SCC, LCC, NSCLC, and SCLC was $72.8 \%$ $(n=16), 4.5 \%(n=1), 4.5 \%(n=1), 9.1 \%(n=2)$, and $9.1 \%$ $(n=2)$, respectively. The ORs and $95 \% \mathrm{Cls}$ are displayed in Table 3 . Smoking was significantly associated with the occurrence of a PF. The prevalence of smoking in patients with a PF was substantially higher than the prevalence of smoking in patients without a PF (95.5\% $[n=21]$ vs. $74.2 \%[n=69] ; p<0.05)$.

Table 1. Clinicopathological characteristics of different histological subtypes of lung cancer in patients with or without bone metastases and pathological fractures.

\begin{tabular}{|c|c|c|c|c|c|c|c|c|c|c|}
\hline \multirow{4}{*}{ Characteristic } & \multicolumn{2}{|c|}{ Lung cancer patients } & \multicolumn{2}{|c|}{ Lung cancer patients } & \multicolumn{2}{|c|}{ Lung cancer patients } & \multicolumn{2}{|c|}{$\begin{array}{l}\text { Lung cancer patients } \\
\text { with bone metastasis }\end{array}$} & \multicolumn{2}{|c|}{$\begin{array}{l}\text { Lung cancer patients } \\
\text { with bone metastasis }\end{array}$} \\
\hline & \multicolumn{2}{|c|}{ cohort overall } & \multicolumn{2}{|c|}{ without bone metastasis } & \multicolumn{2}{|c|}{ with bone metastasis } & \multicolumn{2}{|c|}{$\begin{array}{l}\text { without pathological } \\
\text { fracture }\end{array}$} & \multicolumn{2}{|c|}{ with pathological fracture } \\
\hline & \multicolumn{2}{|c|}{$\mathrm{N}=407$} & \multicolumn{2}{|c|}{$\mathrm{N}=292$} & \multicolumn{2}{|c|}{$N=115$} & \multicolumn{2}{|c|}{$\mathrm{N}=93$} & \multicolumn{2}{|c|}{$\mathrm{N}=22$} \\
\hline & $\mathbf{N}$ & $\%$ & $\mathbf{N}$ & $\%$ & $\mathrm{~N}$ & $\%$ & $\mathbf{N}$ & $\%$ & $\mathbf{N}$ & $\%$ \\
\hline Mean age (range) & \multicolumn{2}{|c|}{63.4 years $(32-87)$} & \multicolumn{2}{|c|}{65.7 years $(42-84)$} & \multicolumn{2}{|c|}{62.6 years $(32-87)$} & \multicolumn{2}{|c|}{$\begin{array}{c}63.6 \text { years } \\
(32-83)\end{array}$} & \multicolumn{2}{|c|}{$\begin{array}{c}64.3 \text { years } \\
(49-87)\end{array}$} \\
\hline \multicolumn{11}{|l|}{ Gender } \\
\hline Male & 250 & 61.4 & 175 & 59.3 & 75 & 65.2 & 61 & 65.6 & 14 & 63.6 \\
\hline Female & 157 & 38.6 & 117 & 40.7 & 40 & 34.8 & 32 & 34.4 & 8 & 36.4 \\
\hline \multicolumn{11}{|l|}{ Smoking } \\
\hline Never smoked & 55 & 13.5 & 30 & 10.3 & 25 & 21.7 & 24 & 25.8 & 1 & 4.5 \\
\hline$<40$ packs/year & 96 & 23.6 & 63 & 21.6 & 33 & 28.7 & 24 & 25.8 & 9 & 41.0 \\
\hline$\geq 40$ packs/year & 256 & 62.9 & 199 & 68.1 & 57 & 49.6 & 45 & 48.4 & 12 & 54.5 \\
\hline \multicolumn{11}{|l|}{ Histology } \\
\hline$A D C$ & 190 & 46.7 & 123 & 42.1 & 67 & 58.3 & 51 & 54.8 & 16 & 72.8 \\
\hline SCC & 102 & 25.1 & 87 & 29.8 & 15 & 13.0 & 14 & 15.1 & 1 & 4.5 \\
\hline LCC & 11 & 2.7 & 9 & 3.1 & 2 & 1.8 & 1 & 1.1 & 1 & 4.5 \\
\hline NOS/NSCLC & 56 & 13.7 & 40 & 13.7 & 16 & 13.9 & 14 & 15 & 2 & 9.1 \\
\hline SCLC & 48 & 11.8 & 33 & 11.3 & 15 & 13.0 & 13 & 14 & 2 & 9.1 \\
\hline
\end{tabular}

ADC: adenocarcinoma; LCC: large cell carcinoma; NOS: not otherwise specified; NSCLC: non-small cell lung cancer, SCLC: small cell lung cancer. 


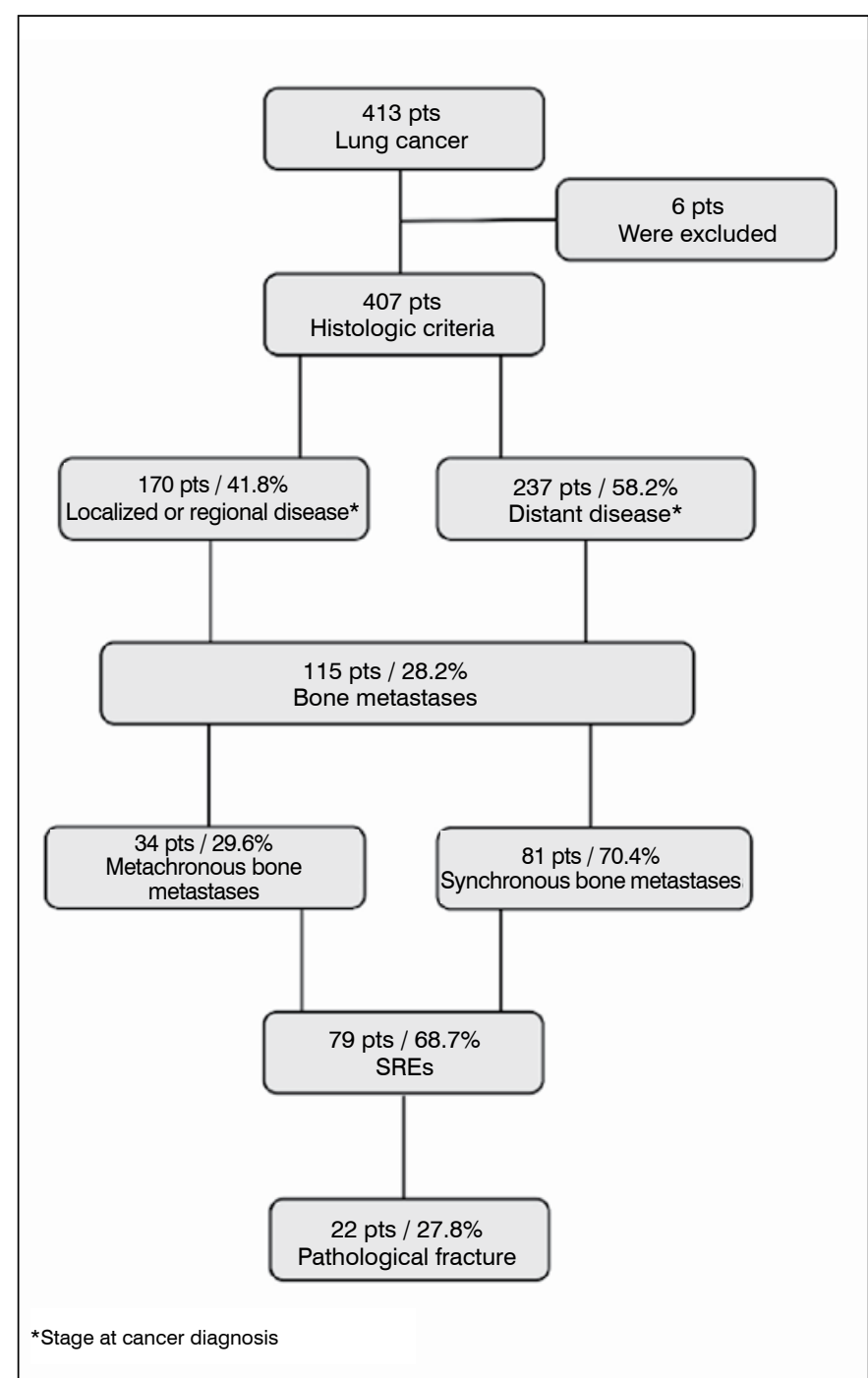

Figure 1. Cohort diagram

The prevalence of a diaphyseal PF (36.0\%) was significantly higher than that of a metaphyseal PF ( $9.5 \%)$, demonstrating an increased risk of a PF in the diaphyseal region (OR: 5.34, $95 \%$ Cl: 1.65-17.2; $p<0.01$ ). PFs were more frequently observed in patients with synchronous BMs (24.7\%) compared to patients with metachronous BMs (5.9 \%) (OR: 5.24, 95 \% Cl: 1.15-23.8; $p<0.05)$.

The primary treatment method for PFs was non-operative, based on immobilization and radiation. Surgical treatment was performed in 8 patients $(36.3 \%)$ through internal fixation with an intramedullary nail $(22.7 \% ; n=5)$ or megaprosthesis replacement $(13.6 \% ; n=3)$. The sample size for analysis of OS was 95 . Twenty patients (17.4\%) were excluded due to the diagnosis of a second malignant primary tumor $(10.4 \% ; n=12)$ or as a result of an unknown date of death $(7.0 \% ; n=8)$. The median OS times following a diagnosis of lung cancer, BMs, and PF were 6 months, 4 months, and 2 months, respectively (Table 4). Kaplan-Meier curves with $95 \%$ Cls are presented in Figure 4.

Median OS times following a diagnosis of BMs were compared between patient groups who developed or did not develop a PF. The median OS times were 7.4 months and 6.4 months, respectively, with no statistical significance $(p>0.05)$. The median OS times of patients with synchronous or metachronous PFs were 3.6 months and 10.7 months, respectively, with no statistical significance $(p>0.05)$.

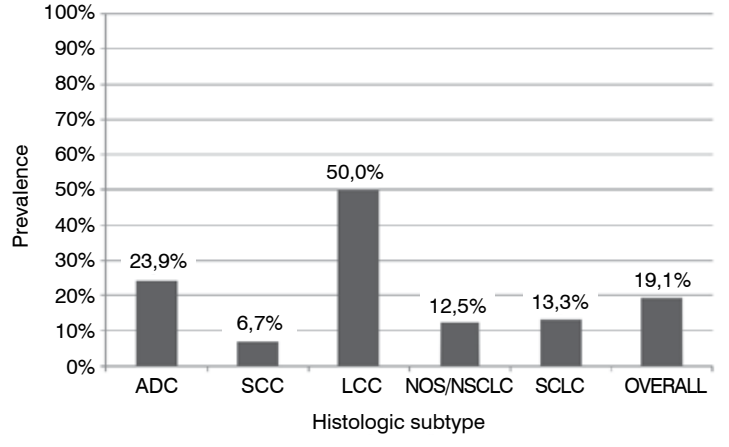

ADC: adenocarcinoma; SCC: squamous cell carcinoma; LCC: large cell carcinoma; NOS not otherwise specified; NSCLC: non-small cell lung cancer, SCLC: small cell lung cancer

Figure 2. Pathological fracture frequency according to lung cancer histology.

\section{DISCUSSION}

The skeleton is one of the most frequent sites of metastatic carcinoma dissemination. ${ }^{6}$ In the present cohort of lung cancer patients treated at a single academic general hospital, $28.3 \%$ of lung cancer patients $(n=115)$ had secondary bone involvement. Studies comparing the frequencies of metastatic sites in NSCLC patients demonstrated a bone dissemination frequency of $20-40 \%$. $^{2,3,7-10}$ Although bone involvement usually means the cancer is incurable, a proportion of patients do survive for prolonged periods. Consequently, these patients are more likely to develop SREs. ${ }^{11}$ Recent advances in the treatment of cancer have prolonged survival..$^{12} \mathrm{As}$ survival increases, SREs, including PFs, are gaining increasing importance, since a prolonged survival increases the risk of such complications over a long period. In the present study, the PF rate reached $19.1 \%$ in patients with secondary bone involvement from lung cancer. This finding was comparable to that of Saad et al. (16.6 $\% ; n=127$ ), who evaluated the significance of PFs in the survival of patients with different primary tumors. ${ }^{11}$

The patients included in the present study had independent risk factors for the occurrence of PFs: the presence of BMs and a lung cancer diagnosis. ${ }^{13}$ In the evaluation of variables associated with the occurrence of PFs, statistical significance was reached for the time of diagnosis or location of BMs and smoking. PFs occurred more frequently in patients with synchronous BMs (24.7\%) compared to patients with metachronous BMs (5.9\%). The frequency of this event was probably higher in the synchronous group, owing to the longer period that these patients are exposed to BMs without specific treatment.

We postulate that the predisposition of cancer patients to developing a PF is multifactorial in origin. In addition to being most obviously and directly related to reduced bone strength, compromised by the presence of metastatic lesions, the risk of developing a PF may also be enhanced by other factors (e.g., immobility, malnutrition, and chemotherapy). Moreover, a major bias is associated with PF risk in lung cancer patients, because of the direct relationship between smoking and lung cancer. However, smoking was independently associated with an increased risk of developing a PF. A previous study reported that smoking increases the PF risk in lung cancer patients, as observed in the present study. ${ }^{14}$ Other possible factors related to the occurrence of a PF include the association between lung cancer and chronic obstructive pulmonary disease and, consequently, the use of corticosteroids that result in bone demineralization. ${ }^{15}$

BMs are associated with a poor prognosis in patients with cancer. ${ }^{16}$ In a study conducted by Sathiakumar et al., the risk of death was 2.4 times higher in patients who developed BMs compared to those who 


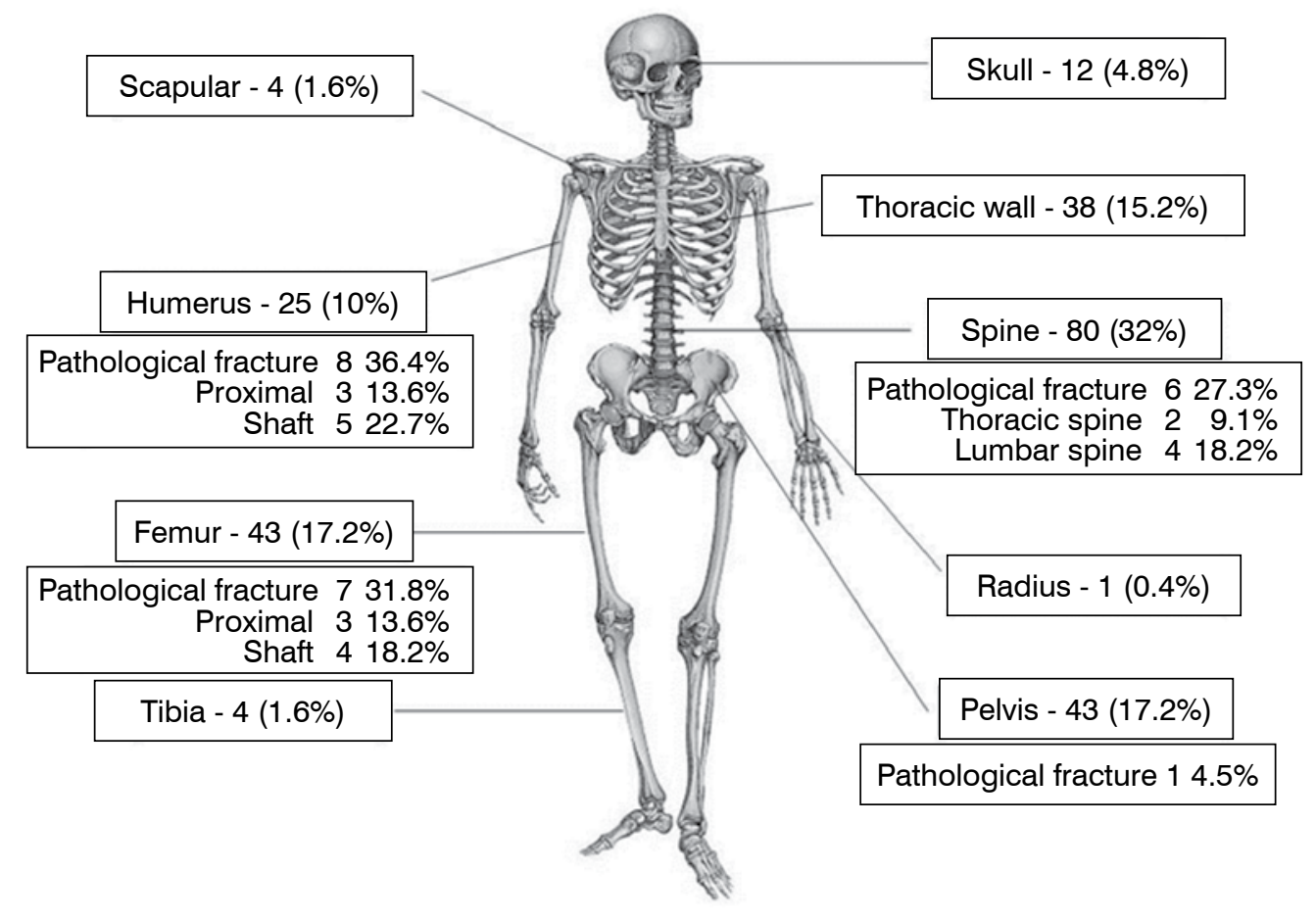

Figure 3. Bone metastases and pathological fracture sites.

Table 2. Analysis of histological subtype, synchronous bone metastases, smoking, and bone location as factors associated with pathological fractures in lung cancer patients.

\begin{tabular}{|c|c|c|c|c|c|c|c|}
\hline & \multicolumn{4}{|c|}{ Pathological Fracture } & \multirow{3}{*}{ OR } & \multirow{3}{*}{ IC (95\%) } & \multirow{3}{*}{ p-value } \\
\hline & \multicolumn{2}{|c|}{ Yes } & \multicolumn{2}{|c|}{ No } & & & \\
\hline & $\mathbf{N}$ & $\%$ & $\mathbf{N}$ & $\%$ & & & \\
\hline \multicolumn{8}{|l|}{ Histology } \\
\hline$A D C$ & 16 & $72.8 \%$ & 51 & $54.7 \%$ & 2.19 & $(0.79-6.11)$ & 0.125 \\
\hline SCC & 1 & $4.5 \%$ & 14 & $15.1 \%$ & 0.26 & $(0.03-2.16)$ & 0.188 \\
\hline LCC & 1 & $4.5 \%$ & 1 & $1.1 \%$ & 4.38 & $(0.26-72.9)$ & 0.262 \\
\hline NOS/NSCLC & 2 & $9.1 \%$ & 14 & $15.1 \%$ & 0.56 & $(0.11-2.68)$ & 0.467 \\
\hline SCLC & 2 & $9.1 \%$ & 13 & $14.0 \%$ & 0.61 & $(0.12-2.95)$ & 0.540 \\
\hline \multicolumn{8}{|l|}{ Bone Metastasis } \\
\hline Synchronous & 20 & $90.1 \%$ & 61 & $65.6 \%$ & \multirow{2}{*}{5.08} & \multirow{2}{*}{$(1.11-23.1)$} & \multirow{2}{*}{0.035} \\
\hline Metachronous & 2 & $9.9 \%$ & 32 & $34.4 \%$ & & & \\
\hline \multicolumn{8}{|l|}{ Smoking } \\
\hline Yes & 21 & $95.5 \%$ & 69 & $74.2 \%$ & \multirow{2}{*}{7.7} & \multirow{2}{*}{$(1.01-67.1)$} & \multirow{2}{*}{0.029} \\
\hline No & 1 & $4.5 \%$ & 24 & $25.8 \%$ & & & \\
\hline \multicolumn{8}{|l|}{ Location } \\
\hline Dyaphyseal & 9 & $60.0 \%$ & 16 & $22.5 \%$ & \multirow{2}{*}{5.34} & \multirow{2}{*}{$(1.65-17.2)$} & \multirow{2}{*}{0.005} \\
\hline Metaphyseal & 6 & $40.0 \%$ & 55 & $77.5 \%$ & & & \\
\hline
\end{tabular}

Table 3. Analysis of overall survival following a diagnosis of lung cancer, bone metastases, and pathological fracture.

\begin{tabular}{c|c|c|c}
\hline & \multicolumn{3}{|c}{ Survival in months after } \\
\hline & Lung cancer & Bone metastases & $\begin{array}{c}\text { Pathological } \\
\text { fracture }\end{array}$ \\
\hline $\mathrm{N}$ & 95 & 95 & 15 \\
\hline Minimum & 0.2 & 0.2 & 0.5 \\
\hline Maximum & 46 & 38.5 & 24 \\
\hline Median & 6 & 4 & 2 \\
\hline Mean & 9.4 & 6.6 & 4.7 \\
\hline
\end{tabular}

did not. ${ }^{17}$ The OS time of patients with BMs from lung cancer was low in the present study. The median OS times following a diagnosis of lung cancer ( 6 months) and BMs (4 months) were shorter than the previous study. The median OS time observed following a diagnosis of lung cancer ( 6 months) in the present study was similar to the OS time predicted ( 7.2 months) in a study conducted by Wao et al.$^{18}$ The present study also demonstrates similar findings to those reported in a French retrospective study in which the median survival time was estimated to be 5.8 months following a diagnosis of BMs. ${ }^{19}$ The median survival times following a diagnosis of lung cancer (6 months) and BMs (4 months) were very similar. The high proportion of patients who had BMs at time of diagnosis of lung cancer (70.4 $\% ; n=81$ ) explains this small difference.

The impact of PFs on the outcome of lung cancer patients may be even greater than predicted because the prevalence of PFs in lung cancer patients may be limited by reduced OS times. Therefore, with increasing survival times due to advances in treatment methods, this problem may become even more relevant.

PFs usually occur 5 months after a diagnosis of BMs and the median OS time after the first event in lung cancer is 5 months. ${ }^{20}$ The median 
Table 4. A comparison of overall survival following a diagnosis of bone metastases in lung cancer patients who developed or did not develop metachronous and synchronous pathological fractures.

\begin{tabular}{|c|c|c|c|c|c|c|c|}
\hline & \multirow{2}{*}{$\mathbf{N}$} & \multicolumn{2}{|c|}{ Survival time* } & \multicolumn{3}{|c|}{ Survival (\%) (Cl 95\%) } & \multirow{2}{*}{ p-valor } \\
\hline & & Mean & Median & 6 months & 12 months & 24 months & \\
\hline \multicolumn{8}{|c|}{ Pathological fracture } \\
\hline Yes & 15 & 7.4 & 3.0 & $\begin{array}{c}40.0 \\
(15.2-64.8)\end{array}$ & $\begin{array}{c}13,3 \\
(0-30.5)\end{array}$ & $\begin{array}{c}13,3 \\
(0-30.5)\end{array}$ & \multirow{2}{*}{0,790} \\
\hline No & 80 & 6.4 & 4.0 & $\begin{array}{c}31.2 \\
(21.1-41.4) \\
\end{array}$ & $\begin{array}{c}13,7 \\
(6.2-21.3) \\
\end{array}$ & $\begin{array}{c}2,5 \\
(0-5.9) \\
\end{array}$ & \\
\hline Sychronous & 7 & 3.6 & 1.5 & $\begin{array}{c}28.6 \\
(0-62.0)\end{array}$ & 0 & 0 & \multirow{2}{*}{0,093} \\
\hline Methachronous & 8 & 10.7 & 6.2 & $\begin{array}{c}50.0 \\
(15.3-84.6)\end{array}$ & $\begin{array}{c}25,0 \\
(0-55.0)\end{array}$ & $\begin{array}{c}25,0 \\
(0-55.0)\end{array}$ & \\
\hline & & & & & & & \\
\hline
\end{tabular}

OS time following a diagnosis of a PF in the present study was even smaller (2 months), as expected, due to the high proportion patients with advanced stage disease. This finding suggests that a PF was a terminal event in our cohort. In the present study, there was no statistically significant difference in the OS times following a diagnosis of BMs in lung cancer patients who developed or did not develop a PF, probably owing to the small number of patients $(n=15)$ who experienced this SRE. Conversely, we exhibited an opposing trend with a longer OS time in patients who experienced a PF. This result may be absolutely justified by the paradoxical effect of the influence of OS on the patient's PF risk. The presence of a PF effectively reduces the OS estimated after its occurrence. However, for comparison between the patient groups, the OS time following a diagnosis of BMs was used. Thus, the higher the OS time the longer the patient had to develop a PF and, therefore, the greater the risk of experiencing this SRE. The patient's OS time before experiencing a PF is correlated with the risk of developing a SRE and is taken into consideration when estimating OS times. According to this method of comparison, when a patient survives with $\mathrm{BMs}$ for a longer period before the occurrence of a PF, the effect in reducing the OS time is even more underestimated. In contrast, patients who survive for a short time following a diagnosis of BMs may not have sufficient time to experience a PF. Therefore, the short OS time (2 months) following a diagnosis of a PF should be noted. One interesting observation that eliminates the effect of the OS time prior to the development of BMs and supports the above is the analysis of patients who experienced a synchronous PF. The shortest OS time in the univariate analysis was recorded in this group. The median OS time in this group was 1.5 months, compared to 6.2 months in the patient group who experienced a metachronous PF. Synchronous PFs determine a similar OS time following a diagnosis of lung cancer, BMs, and a PF. The present study did not have sufficient power to detect the statistical significance of differences in OS time in relation to the occurrence of a PF due the small number of patients in each group. However, the observation of this trend is relevant. In addition, the progressively shorter OS times following a diagnosis of lung cancer (6 months), BMs (4 months), and a PF (2 months) reflects the general developmental stages of compatible disease with its natural history. This allows us to infer that the occurrence of a PF is a terminal event in the course of the disease and the OS time after this SRE is considerably shorter. The precise correlation between PFs and decreased OS rates in patients with BMs from lung cancer has yet to be fully elucidated. Several factors may be involved, including increased mortality from PF surgery, loss

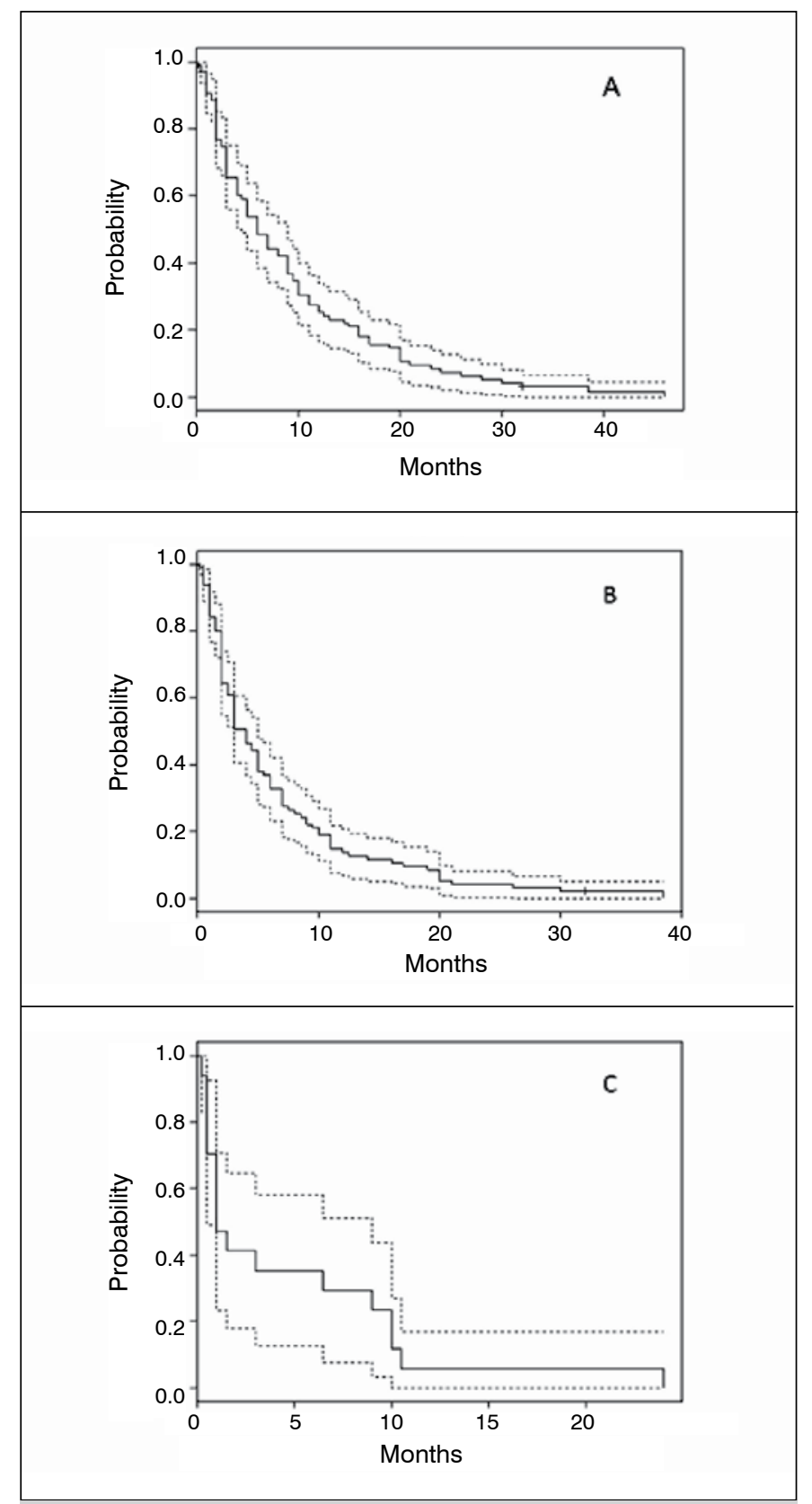

Figure 4. Kaplan-Meier survival curves of overall survival following a diagnosis of $(A)$ lung cancer, $(B)$ bone metastases, and $(C)$ pathological fracture.

of functional independence, increased risk of deep vein thrombosis, and other complications (e.g., clinical changes and disease biology). ${ }^{20}$ BMs are associated with a poor prognosis in lung cancer patients. Moreover, lung cancer patients with BMs are more likely to experience SREs, including PFs that correlate with increased mortality, the use of financial resources, and a reduced quality of life. With the advancement of other therapies, especially chemotherapy, increased survival and the prevention of bone-related complications through pharmacological and surgical interventions will become even more important in the management of this disease.

In conclusion, the occurrence of PFs in lung cancer patients was associated with synchronous BMs, diaphyseal location, and smoking. OS times following a diagnosis of PF were considerably reduced, suggesting a terminal stage of disease. 
AUTHORS' CONTRIBUTIONS: Each individual author contributed individually and significantly to the development of this work. MBRO (0000-0003-19867002)*: wrote, reviewed, performed the procedures, analyzed the data, evaluated the medical records; BCM (0000-0002-0479-0244)*: wrote the article evaluated the medical records RAM (0000-0002-1502-8394)*: analyzed the data; and reviewed the article; CRCF (0000-0003-1802-0037)* evaluated the plain films and reviewed the article; FCQM (0000-0003-3250-6738)*: drafted and reviewed the article and contributed to the intellectual concept of the study; MEMP (0000-0002-8699-3933)*: wrote the article, performed statistical analysis and contributed to the intellectual concept of the study and the entire research project. *ORCID (Open Researcher and Contributor ID).

\section{REFERENCES}

1. Kuchuk M, Kuchuk I, Sabri E, Hutton B, Clemons M, Wheatley-Price P. The incidence and clinical impact of bone metastases in non-small cell lung cancer. Lung Cancer. 2015;89(2):197-202.

2. Langer $\mathrm{C}$, Hirsh V. Skeletal morbidity in lung cancer patients with bone metastases: demonstrating the need for early diagnosis and treatment with bisphosphonates. Lung Cancer. 2010;67(1): 4-11.

3. Oliveira MBR, Mello FCQ, Paschoal MEM. The Relationship between lung cancer histology and the clinicopathological characteristics of bone metastases. Lung Cancer. 2016;96:19-24.

4. Oliveira MB, Souza LC, Sampayo EJG, Carvalho GS, Mello FCQM, Paschoal MEM. O impacto da histologia do carcinoma pulmonar na frequência das metástases ósseas. Rev Bras Ortop. 2018.

5. Travis WD, Brambilla E, Noguchi M, Nicholson AG, Geisinger KR, Yatabe $Y$, et al. International association for the study of lung cancer/american thoracic society/european respiratory society international multidisciplinary classification of lung adenocarcinoma. J Thorac Oncol. 2011;6(2):244-85.

6. Brodowicz T, O'Byrne K, Manegold, C. Bone matters in lung cancer. Ann Oncol. 2012;23(9):2215-22.

7. Kuchuk M, Addison CL, Clemons M, Kuchuk I, Whatley-Price P. Incidence and consequences of bone metastases in lung cancer patients. J Bone Oncol. 2013;2(1):22-9.

8. Lee DS, Kang JH, Lee CG, Kim SJ, Choi YJ, Lee KY, et al. Predicting Survival in Patients with Advanced Non-squamous Non-small Cell Lung Cancer: Validating the Extent of Metastasis. Cancer Res Treat. 2013;45(2):95-102.

9. Tsuya A, Kurata T, Tamura K, Fukuoka M. Skeletal metastases in non-small cell lung cancer: a retrospective study. Lung Cancer. 2007;57(2):229-32.

10. Kosteva J, Langer C. Incidence and distribution of skeletal metastases in NSCLC in the era of PET. Lung Cancer. 2004;46(1):S45.

11. Saad F, Lipton A, Cook R, Chen YM, Smith M, Coleman R. Pathologic fractures correlate with reduced survival in patients with malignant bone disease. Cancer 2007;110(8):1860-7.

12. Kishimoto Y, Iwase T, Yano T, Mori H. Reossification of osteolytic metastases at the acetabulum following gefitinib and multidisciplinary treatment for lung cancer: a case report with autopsy findings. J Orthop Sci. 2015;20(5):914-8.

13. Vestergaard $P$, Rejnmark $L$, Mosekilde $L$. Fracture risk in patients with different types of cancer. Acta Oncol. 2009;48(1):105-15.

14. Vestergaard P, Mosekilde L. Fracture risk associated with smoking: a meta-analysis. J Intern Med. 2003;254(6):572-83.

15. Vestergaard $P$, Rejnmark L, Mosekilde L. Fracture risk associated with systemic and topical corticosteroids. J Intern Med. 2005;257(4):374-84.

16. Sekine I, Nokihara H, Yamamoto N, Kunitoh H, Ohe Y, Tamura T. Risk factors for skeletal-related events in patients with non-small cell lung cancer treated by chemotherapy. Lung Cancer. 2009;65(2):219-22.

17. Sathiakumar N, Delzell E, Morrisey MA, Falkson C, Yong M, Chia V, et al. Mortality following bone metastasis and skeletal-related events among patients 65 years and above with lung cancer: A population-based analysis of U.S. Medicare beneficiaries, 1999-2006. Lung India. 2013;30(1):20-6.

18. Wao H, Mhaskar R, Kumar A, Miladinovic B, Djulbegovic B. Survival of patients with non-small cell lung cancer without treatment: a systematic review and meta-analysis. Syst Rev. 2013;2:10.

19. Decroisette C, Monnet I, Berard H, Quere G, Le Caer H, Bota S, et al. Epidemiology and treatment costs of bone metastases from lung cancer: a French prospective, observational, multicenter study (GFPC 0601). J Thorac Oncol. 2011;6(3):576-82.

20. Cetin K, Christiansen CF, Jacobsen JB, Norgaard M, Sorensen HT. Bone metastasis, skeletal-related events, and mortality in lung cancer patients: a Danish population-based cohort study. Lung Cancer. 2014;86(2):247-54. 